\title{
Cancer incidence in a cohort of Swedish merchant seafarers between 1985 and 2011
}

\author{
Karl Forsell ${ }^{1,3} \cdot$ Ove Björ $^{2} \cdot$ Helena Eriksson ${ }^{1} \cdot$ Bengt Järvholm ${ }^{3} \cdot$ Ralph Nilsson $^{1} \cdot$ Eva Andersson ${ }^{1}$
}

Received: 9 August 2021 / Accepted: 21 December 2021 / Published online: 8 January 2022

(c) The Author(s) 2021

\begin{abstract}
Purpose Lung cancer, mesothelioma and several lifestyle-associated cancer forms have been reported more common in merchant seafarers. However, few studies reflect recent occupational settings and women seafarers are usually too scarce for meaningful analyses. We conducted a study on cancer incidence between 1985 and 2011 in a Swedish cohort consisting of male and female seafarers.

Methods All seafarers in the Swedish Seafarers' Register with at least one sea service between 1985 and 2011 and a cumulated sea service time of $\geq 30$ days ( $N=75,745 ; 64 \%$ men, $36 \%$ women; $1,245,691$ person-years) were linked to the Swedish Cancer Register and followed-up until 31 December 2011. Standardized incidence ratios (SIR) were calculated with the general population as reference.

Results There were 4159 cancer cases in total, with 3221 among men and 938 among women. Male seafarers had an increased risk of total cancer (SIR 1.05; 95\% CI 1.01-1.09), lung cancer (SIR 1.51; 95\% CI 1.35-1.67) and urinary bladder cancer (SIR 1.17; 95\% CI 1.02-1.33). Several lifestyle-associated cancer forms were more common in men. Previous work on tankers was associated with leukaemia (SIR 1.41; 95\% CI 1.00-1.86). The risk of cancer decreased with a start as a male seafarer after 1985, with a significant trend for total cancer $(P<0.001)$, lung cancer $(P=0.001)$ and, for tanker seafarers, leukaemia $(P=0.045)$. Women seafarers had an increased risk of lung cancer (SIR 1.54; 95\% CI 1.23-1.87) but the risk of total cancer was not increased (SIR 0.83 ; 95\% CI 0.78-0.89).

Conclusions In this cohort of merchant Swedish seafarers 1985-2011, the risk of total cancer was increased in men but not in women compared to the general population. Lung cancer was increased in both genders. The risk of cancer seems to decrease over the last decades, but better exposure assessments to occupational carcinogens and longer observation times are needed.
\end{abstract}

Keywords Cohort $\cdot$ Follow-up $\cdot$ Neoplasm (epidemiology) $\cdot$ Occupational disease (epidemiology) $\cdot$ Risk factor $\cdot$ Cancer incidence $\cdot$ Seafarer $\cdot$ Sweden $\cdot$ Occupational exposure $\cdot$ Lifestyle $\cdot$ Record linkage

\section{Background}

In 1998, a Swedish epidemiological cancer study on Swedish male merchant seafarers from national census, found an increased risk of total cancer by 29\% (Standardized Incidence Ratio, SIR, 1.29; 95\% confidence interval, CI 1.22-1.39)

Karl Forsell

karl.forsell@amm.gu.se

1 Occupational and Environmental Medicine, Sahlgrenska Academy, Gothenburg University, Gothenburg, Sweden

2 Department of Radiation Science, Oncology, Umeå University, Umeå, Sweden

3 Department of Public Health and Clinical Medicine, Section of Sustainable Health, Umea University, Umea, Sweden
(Nilsson 1998). The reference group consisted of all economically active men in Sweden. Lung cancer and mesothelioma were more common, especially among the engine room crewmembers. Other epidemiological studies, most performed on Nordic seafarers, have shown similar results together with increased risks of cancer of the urinary bladder, stomach, lip, skin, pancreas and the prostate (Greenberg 1991; Pukkala and Saarni 1996; Saarni et al. 2002; Rafnsson and Sulem 2003; Pukkala et al. 2009). There are several occupational factors present in seafaring that may explain an increased risk of cancer. Asbestos, from the ships interior or cargo, may cause pleural mesothelioma and lung cancer in seafarers (IARC 1987, 2012; Saarni et al. 2002; Forsell et al. 2007, 2017; Ugelvig Petersen et al. 2018). Exposures to polyaromatic hydrocarbons (PAHs) present in soot, exhausts and in contaminated oils may 
be involved in the aetiology of bladder cancer, lung cancer and skin cancer (IARC 1984a, 1984b, 2006, 2013; Moen et al. 1996; Boffetta et al. 1997, 2001; Nilsson et al. 2004; Kaerlev et al. 2005; Forsell et al. 2007; Olsson et al. 2010). The sun's ultraviolet radiation ( $\mathrm{UV}$ radiation) is a carcinogenic exposure when working outside on a ship, with increased risks of skin and lip cancer (Pukkala et al. 2009; Oldenburg et al. 2015; IARC 2018; Ugelvig Petersen et al. 2018). Certain lifestyleassociated factors of cancer may be more prominent among seafarers, such as tobacco smoking, alcohol use and infections (Greenberg 1991; Pukkala and Saarni 1996; Kaerlev et al. 2005).

A special group of interest has been seafarers working on tankers, where important exposures to the carcinogen benzene have been demonstrated (Moen et al. 1993, 1995; Nilsson et al. 1996; Forsell et al. 2019). Furthermore, tanker crewmembers have shown increased risks of leukaemia and other blood malignancies (Nilsson et al. 1998; Saarni et al. 2002; Forsell et al. 2020), indicating a carcinogen effect from such occupational benzene exposure.

An eventual effect on cancer incidence from ship modernization and an improved safety climate, especially for Nordic seafarers, is not known. Examples of such are the step-wise reduction of threshold limit values for several carcinogenic chemicals (IMO 1974, 2000, 2003, 2011) and the introduction of closed handling of chemical cargoes (Mowe et al. 1977; Moen et al. 1988; Williams et al. 2005; Kirkeleit et al. 2006; Forsell et al. 2019).

Cancer among women seafarers is seldom reported since the population has been limited in numbers, although their number has increased in Nordic countries to actually represent around $20-30 \%$ of the work force (Kaerlev et al. 2005; Forsell et al. 2017). A Danish study with a follow-up of 1986-1999 reported increased incidences compared to the general female population for total cancer and for the following sites: pharynx, oesophagus, rectum, liver, gallbladder and bile ducts, lung (including bronchus and trachea), cervix uteri and ovaries (Kaerlev et al. 2005). An older Finnish study also found higher cancer incidence among women seafarers from all sites, mouth and pharynx, larynx, lung and bronchus and cervix uteri and breast cancer (Pukkala and Saarni 1996).

The aims of the present study were to investigate any change in cancer incidence among Swedish merchant seafarers between 1985 and 2011, and to identify any groups of seafarers by gender or work category at special risk of cancer.

\section{Materials and methods}

This longitudinal cohort study on Swedish seafarers was enabled through matching the Swedish Seafarers Register (SR) with the Swedish Cancer Register (CR). All Swedish seafarers have to be registered in the SR. The SR is administered by the Swedish Transport Agency, and it holds information on seafarer's time and length of sea services, type of ship the service took place on and the seafarer's position on board. Our initial cohort consisted of all seafarers with any registered sea service from 1985 , corresponding to the start of the digitization of the SR, up to $2013(n=105,098)$. However, since information on any sea service before 1985 had during the digitization been manually entered by the Authority (only for seafarers in service at that time), we could consider even this data when assessing the cumulative sea service time per seafarer. We excluded non-Swedish citizens $(n=9536)$, seafarers deceased before 1985 $(n=101)$, with re-used PINs $(n=50)$ or born before 1920 $(n=198)$. The last group was excluded since they would have been $>65$ years, the usual retirement age, when the observation period started. Seafarers with a cumulative service time of $<30$ days were also excluded $(n=7223)$ to avoid short-term workers at sea. Finally, since we only got data on cancer up to 2011 from the CR at the start of the study, seafarers with sea services only between 2011 and 2013 were excluded $(n=12,245)$.

Among those 75,745 included in the cohort, 21582 had their first sign on before 1985. There were about 20,000 cohort members in the register each year, with a maximum of 25,693 registered in 1992, then slowly decreasing. We used the definition of a merchant ship as any vessel that transports cargo or carries passengers. Seafarers could have worked on ships of any flag. The number of ships sailing the Swedish flag has diminished a lot from the 70'ies until now. However, there has been a relatively stable numbers of registered seafarers during 1985 to 2011.

The CR is hold by the National Board of Health and Welfare and started in 1958. Physicians are obliged to report any new malignancy to the register. Tumours from CR were classified according to the International Classification of Diseases (ICD-7). The Swedish Transport Agency sent the SR data to Statistics Sweden for data on migration or other vital events, and thereafter to the National Board of Health and Welfare for linkage with the CR. Record linkage was done by the subjects' personal identity number (PIN). All data were anonymised by the Board before transferral to us.

\section{Statistical analysis}

The seafarers were classified by sea service position as 'ever deck rating', 'ever deck officer', 'ever engine rating', 'ever engine officer' and 'ever catering/service'. We also analysed cancer and 'ever work on tankers'. In the analyses, we used a minimum of 30 days of cumulated service time per such work category.

Person-years at risk were calculated starting from 1 January 1985, age of 20 years or first time of sea service in SR if 
later and until first emigration, time of death, age of 85 years or end of follow-up 31 December 2011. The person-years were stratified by gender, 5-year age groups and 1-year calendar periods. The expected number of cancer cases for these strata was calculated using the general Swedish population as reference. SIR was then achieved by dividing the observed by the expected number of cancer cases with a 95\% CI. For the CI, we assumed a Poisson distribution for the number of observed cancer cases. Data on cancers were analysed when the number of observed cases was $>3$. Age and cumulated time of sea services are given with the median with its first and third quartiles (Q1 and Q3, respectively).

SIRs were calculated for the whole follow-up and for three different calendar periods, each defined by the first registered sea service of each seafarer $(<1985 ; 1985-1991 ; \geq 1992)$. We tested for trend between different SIRs of the three calendar periods using $\mathrm{Chi}^{2}$ test of trend as described by Breslow and Day (Breslow and Day 1987). Further analyses included a 10 years' latency, a cumulative sea service time of 5 years or more and haematologic malignancy among seafarers who had worked on tankers. The last analysis was restricted to men since few women had worked on tankers. All analyses were made using R 3.2.2 and SAS 9.4.

The study was approved by the Regional Ethical Committee of Gothenburg (193-13).

\section{Results}

The final cohort consisted of 75,745 seafarers, $36 \%$ women, $64 \%$ men, representing in total 1,245,691 person-years at risk (Table 1). Age at start of follow-up in three age spans are given in Table 1 . The median age at the end of the observation period was 45 years (Q1 35 years; Q3 56 years), which was similar for both sexes (data not shown). The median employment time of a seafarer was 4 years (Q1 1 year; Q3 15 years), with a median of 7 years for men and 2 years for women (further information in Table 1). During the observation period, 6835 (9\%) emigrated and 4876 (6\%) died.

Fifty-one percent of male seafarers had ever worked in the deck department, 24\% in the engine department and 37\% in the catering/service department (Table 1). Of women, $90 \%$ had ever worked in the catering or service department. Apart from catering many of the seafarers had worked at different positions and ships. Twenty-seven percent of men, but only $5 \%$ of women, had ever worked on tankers. Eighty percent of women and $40 \%$ of men had only worked on passenger ships. Besides passenger ships, the most common ships were cargo ships. Twenty-eight percent of all seafarers had had their first registered sea service before 1985, 26\% between 1985 and 1991 and 46\% in 1992 or later (data not shown).

There were 4,159 cases of cancer in the cohort. The majority of cancer cases, $71 \%$, had occurred among seafarers with their first registered sea service before $1985,18 \%$ with first sea service 1985-1991 and 11\% in 1992 or later (data not shown).

\section{Cancer in male seafarers}

The incidence of total cancer among male seafarers was increased (Table 2). A SIR of 1.15 was noted for deck officers. Cancers of the lung, the urinary bladder, mouth/pharynx, oesophagus and the larynx were all more common than in the general population (Table 3). Lung cancer was more common in all departments or rank, with the most elevated SIR for engine ratings (Table 2). Malignant melanoma and other skin cancer were not significantly increased. Neither was the incidence of cancer of the tongue, stomach, liver, colon/rectum nor pancreas (Table 3 ).

Applying a minimum of 5 years of cumulated sea service to the analyses increased the already elevated SIRs (Table 3). The risk of lip cancer then was significantly increased. Applying a 10 years lag between first sea service and time of diagnosis had no apparent effect on the SIRs other than a small increase in general (Table 4). Comparing incidence of cancer in seafarers with a first sea service before 1985 with seafarers with a later first employment, we found a significant trend of a decreased risk of cancer. This trend was supposedly an effect of a sharp decline in the lung cancer risk (Table 5).

There were in total 16 cases of mesothelioma, and all had occurred among seafarers with their first employment before 1985. Eleven of these cases, compared to 4 expected cases, had occurred among ever engine room crewmembers (SIR 2.59 ; 95\% CI 1.18-4.23).

Seafaring men had fewer cases of prostate and thyroid cancer than expected (Table 3).

The analysis on haematologic malignancy amongst men having served on tankers revealed 83 cases in total, which was similar to the expected number $(n=78)$. However, there were more cases of leukaemia than expected (Table 5). The SIR of haematologic malignancy decreased across the three calendar periods, with a significant trend for leukaemia (Table 5).

\section{Cancer in women seafarers}

There were significantly less cases of cancer among women seafarers than expected (938 observed vs. 1127 expected) (Table 2). No position showed an increased risk for total cancer. Lung cancer, however, was significantly more common among women seafarers. Almost every lung cancer case had worked in the catering department ( $n=81$ out of 84 cases) (Table 2$)$ and the majority $(n=48)$ had occurred in the group of seafarers with a first employment before 1985 (data not shown). There were no cases of mesothelioma amongst 
Table 1 Characteristics (selected) of the cohort of men and women Swedish seafarers between 1985 and 2011

\begin{tabular}{|c|c|c|c|}
\hline & $\begin{array}{l}\text { Total } \\
\text { Person-years }\end{array}$ & $\begin{array}{l}\text { Men } \\
\text { Person-years }\end{array}$ & $\begin{array}{l}\text { Women } \\
\text { Person-years }\end{array}$ \\
\hline Person-years for all seafarers & $1,245,691$ & 823,523 & 422,168 \\
\hline Start $<1985$ & 510,228 & 409,402 & 100,827 \\
\hline Start 1985-1991 & 414,350 & 214,096 & 200,254 \\
\hline \multirow[t]{2}{*}{ Start $>1992$} & 321,113 & 200,025 & 121,087 \\
\hline & $n$ & $n$ & $n$ \\
\hline Total numbers of seafarers & 75,745 & 48,787 & 26,958 \\
\hline \multicolumn{4}{|l|}{ Position $^{\mathrm{a}}$} \\
\hline \multicolumn{4}{|l|}{ Deck } \\
\hline Total & 28,211 & 24,915 & 3296 \\
\hline Officers & 9261 & 8858 & 403 \\
\hline Ratings & 26,200 & 23,079 & 3121 \\
\hline \multicolumn{4}{|l|}{ Engine } \\
\hline Total & 12,202 & 11,924 & 278 \\
\hline Officers & 5940 & 5861 & 79 \\
\hline Ratings & 10,761 & 10,502 & 259 \\
\hline Catering/service & 42,300 & 17,949 & 24,351 \\
\hline \multicolumn{4}{|l|}{ Tankers $^{\mathrm{a}}$} \\
\hline Total & 14,596 & 13,197 & 1399 \\
\hline Deck & 8475 & 8061 & 414 \\
\hline \multicolumn{4}{|l|}{ Vital status 31st Dec 2011} \\
\hline Alive & 64,034 & 40,473 & 23,561 \\
\hline Dead & 4876 & 4167 & 709 \\
\hline Emigrated & 6835 & 4147 & 2688 \\
\hline \multicolumn{4}{|l|}{ Age at start of follow-up } \\
\hline$<30$ years & 48,404 & 28,146 & 20,258 \\
\hline $30-59$ years & 26,240 & 19,748 & 6492 \\
\hline$\geq 60$ years & 1,101 & 893 & 208 \\
\hline \multicolumn{4}{|c|}{ Time first to last sea service until 2011} \\
\hline$<1$ year & 17,419 & 9518 & 7901 \\
\hline $1-5$ year & 23,075 & 12,456 & 10,619 \\
\hline $5-10$ years & 10,173 & 6176 & 3997 \\
\hline$\geq 10$ years & 25,078 & 20,637 & 4441 \\
\hline
\end{tabular}

aAnalysis based on "ever" having held such a position (overlap possible) women (Table 3). Breast cancer, cancer of the uterus, thyroid cancer and leukaemia were all less common than in the general female population (Table 3). The incidence of cancer of the cervix uteri was not increased, which was true also for malignant melanoma or other skin cancer.

Even with a minimum of 5 years of cumulated sea service women seafarers had less cancer cases than expected for all sites together (Table 3). Lung cancer incidence was still increased.

\section{Discussion}

This cohort study with a follow-up for cancer in Swedish seafarers between 1985 and 2011 showed cancer to be more common in male seafarers and less common in women seafarers compared with the general Swedish population. The increased risk of cancer was associated primarily with seafarers with a first sea service before 1985. Higher incidences of lung cancer in both men and 
Table 2 Standardized Incidence Ratio (SIR) for total cancer and lung cancer in Swedish seafarers 1985-2011 per position ("ever") and gender

\begin{tabular}{|c|c|c|c|c|}
\hline & \multicolumn{2}{|l|}{ Men } & \multicolumn{2}{|c|}{ Women } \\
\hline & Obs & SIR $(95 \%$ CI) & Obs & SIR $(95 \%$ CI) \\
\hline \multicolumn{5}{|l|}{ Total cancer } \\
\hline All positions & 3221 & 1.05 (1.01-1.09) & 938 & $0.83(0.78-0.89)$ \\
\hline \multicolumn{5}{|l|}{ Deck* } \\
\hline Officers & 1137 & $1.15(1.08-1.21)$ & 27 & $1.15(0.73-1.62)$ \\
\hline Ratings & 1717 & $1.08(1.03-1.13)$ & 51 & $0.73(0.54-0.93)$ \\
\hline \multicolumn{5}{|l|}{ Engine $^{a}$} \\
\hline Total & 1066 & $1.07(1.00-1.13)$ & 4 & $0.67(0.17-1.33)$ \\
\hline Officers & 691 & $1.06(0.98-1.14)$ & $\leq 3$ & (expected 2) \\
\hline Ratings & 903 & $1.12(1.05-1.19)$ & 4 & $0.72(0.18-1.45)$ \\
\hline Catering/service ${ }^{\mathrm{a}}$ & 727 & $1.04(0.96-1.11)$ & 880 & $0.83(0.77-0.88)$ \\
\hline Tankers, all positions & 941 & $1.08(1.01-1.15)$ & 65 & $0.94(0.72-1.17)$ \\
\hline \multicolumn{5}{|l|}{ Lung cancer } \\
\hline All positions & 341 & $1.51(1.35-1.67)$ & 84 & $1.54(1.23-1.87)$ \\
\hline \multicolumn{5}{|l|}{$\operatorname{Deck}^{\mathrm{a}}$} \\
\hline Officers & 108 & $1.38(1.12-1.65)$ & 4 & $3.07(0.77-6.14)$ \\
\hline Ratings & 186 & $1.57(1.35-1.79)$ & $\leq 3$ & expected 3 \\
\hline \multicolumn{5}{|l|}{ Engine $^{a}$} \\
\hline Total & 125 & $1.64(1.36-1.93)$ & 0 & expected 0 \\
\hline Officers & 76 & $1.49(1.15-1.84)$ & 0 & expected 0 \\
\hline Ratings & 111 & $1.82(1.49-2.16)$ & 0 & expected 0 \\
\hline Catering/service ${ }^{\mathrm{a}}$ & 74 & 1.58 (1.24-1.95) & 81 & $1.57(1.24-1.92)$ \\
\hline Tankers, all positions & 121 & $1.87(1.54-2.21)$ & 6 & $1.68(0.56-3.08)$ \\
\hline
\end{tabular}

Obs observed cases; $C I$ confidence interval

aAnalysis based on "ever" having held such a position (overlap possible) women and of urinary bladder cancer in men were noted. Male engine room ratings had an almost doubled risk of lung cancer. Male engine room crewmembers employed before 1985 had an increased risk of mesothelioma. Work on tankers was associated with leukaemia.

The strength of the study is the robustness of data of both independent and dependant variables coming from state-hold registries. One limitation is the fact that the SR lacks information on seafarers that stopped working prior to its digitization in 1985. Another limitation is that we had no knowledge of the type of cargo associated with any sea service, since cargo is not noted in the SR. However, type of ship was noted, which enabled us to analyse associations between blood malignancies and work on tankers. We share the same limitations as other Nordic studies on cancer in seafarers with the exclusion of a foreign workforce, short cumulated sea service time per seafarer and no direct information on lifestyle factors. We also did not have information on other occupations held by the seafarers either before, during and/or after work at sea.

Increased cancer risks were primarily associated with an early start in seafaring $(<1985)$ and there was a decreasing trend in cancer with later first employments. However, our material was not sufficient to assess cancer risks with later sea starts, since that group of seafarers had a shorter followup and the number of cases were few. Increased risks of cancer in seafarers reported in the literature stem primarily from older periods of seafaring up to 1999 at the latest (Pukkala and Saarni 1996; Kaerlev et al. 2005; Ugelvig Petersen et al. 2018; Ugelvig Petersen et al. 2020). Our study pushed this exposure window a bit further, up to 2011. Preferably, other Nordic cohorts can be up-dated with more recent exposure data to corroborate our results of a diminished cancer risk in more recent sea services.

Furthermore, studies on cancer in seafarers generally lack a good measure of exposure to known or suspected carcinogens: there are few on-site measurements, exposures are complex and the length of exposure is seldom known. Therefore, the exposure assessment is usually rather crude and essentially based on 'department' or 'last held position'. The rationale for this method implies that seafarers usually work in one category during his or her whole career at sea (Kaerlev et al. 2005; Oldenburg et al. 2015; Ugelvig Petersen et al. 2018). Except for catering, we have observed that an overlap is common between different job departments or job positions (Eriksson et al. 2020). A risk of misclassification of exposure may thus exist. Using 'ever' in our analyses for the independent variables, we sought to reduce this risk of 
Table 3 Standardized Incidence Ratio (SIR) by specific site for cancer 1985-2011 among Swedish seafarers, men and women

\begin{tabular}{|c|c|c|c|c|c|}
\hline \multirow[t]{2}{*}{ ICD-7 } & \multirow[t]{2}{*}{ Cancer } & \multicolumn{2}{|l|}{ Men } & \multicolumn{2}{|c|}{ Women } \\
\hline & & Obs & $\operatorname{SIR}(95 \% \mathrm{CI})$ & Obs & SIR $(95 \% \mathrm{CI})$ \\
\hline \multirow[t]{2}{*}{140} & Lip & 17 & $1.63(0.86-2.50)$ & $\leq 3$ & \\
\hline & $\geq 5$ years cumulative sea service & 16 & $1.96(1.10-2.94)$ & & \\
\hline 141 & Tongue & 20 & $1.25(0.75-1.81)$ & $\leq 3$ & \\
\hline \multirow[t]{2}{*}{$143-148$} & Mouth, pharynx & 76 & $1.66(1.29-2.05)$ & 4 & $0.56(0.14-1.12)$ \\
\hline & $\geq 5$ years cumulative sea service & 66 & $2.02(1.56-2.51)$ & & \\
\hline \multirow[t]{2}{*}{150} & Oesophagus & 54 & $1.52(1.13-1.94)$ & $\leq 3$ & \\
\hline & $\geq 5$ years cumulative sea service & 45 & $1.64(1.17-2.15)$ & & \\
\hline 151 & Stomach & 78 & $1.14(0.89-1.40)$ & 12 & $0.95(0.48-1.51)$ \\
\hline 153 & Colon & 193 & $1.01(0.87-1.15)$ & 50 & $0.91(0.68-1.17)$ \\
\hline 154 & Rectum & 141 & $1.06(0.89-1.25)$ & 26 & $0.87(0.57-1.20)$ \\
\hline 155.0 & Liver & 34 & $1.04(0.70-1.41)$ & $\leq 3$ & \\
\hline $155.1-9$ & Gallbladder & 14 & $0.80(0.40-1.25)$ & $\leq 3$ & \\
\hline 157 & Pancreas & 52 & $0.87(0.64-1.12)$ & 15 & $1.00(0.53-1.53)$ \\
\hline 160 & Nasal cavity & 6 & $1.07(0.36-1.95)$ & $\leq 3$ & \\
\hline \multirow[t]{2}{*}{161} & Larynx & 44 & $1.98(1.40-2.57)$ & 4 & $3.10(0.78-6.20)$ \\
\hline & $\geq 5$ years cumulative sea service & 38 & $2.21(1.51-2.97)$ & & \\
\hline \multirow[t]{2}{*}{162.1} & Lung & 341 & $1.51(1.35-1.67)$ & 84 & $1.54(1.23-1.87)$ \\
\hline & $\geq 5$ years cumulative sea service & 183 & $1.61(1.43-1.80)$ & 43 & $1.61(1.16-2.10)$ \\
\hline 162.2 & Pleura (mesothelioma) & 16 & $1.29(0.73-1.93)$ & & \\
\hline 170 & Breast & & & 291 & $0.74(0.65-0.82)$ \\
\hline 171 & Cervix uteri & & & 49 & $0.96(0.71-1.24)$ \\
\hline 172 & Uterus & & & 27 & $0.58(0.36-0.81)$ \\
\hline 175 & Ovaries & & & 46 & $1.02(0.73-1.32)$ \\
\hline 177 & Prostate & 812 & $0.92(0.86-0.98)$ & & \\
\hline 178 & Testis & 77 & $1.02(0.79-1.26)$ & & \\
\hline 179 & Male genitals & 10 & $0.90(0.36-1.54)$ & & \\
\hline 180 & Kidney & 79 & $0.86(0.68-1.06)$ & 18 & $1.10(0.61-1.65)$ \\
\hline \multirow[t]{2}{*}{181} & Urinary bladder & 218 & $1.17(1.02-1.33)$ & 12 & $0.70(0.35-1.11)$ \\
\hline & $\geq 5$ years cumulative sea service & 183 & $1.26(1.08-1.44)$ & 8 & $0.91(0.34-1.58)$ \\
\hline 190 & Malignant melanoma & 176 & $1.04(0.88-1.19)$ & 75 & $0.90(0.71-1.10)$ \\
\hline 191 & Other skin & 177 & $1.12(0.95-1.29)$ & 22 & $0.71(0.42-1.04)$ \\
\hline 193 & Brain & 107 & $0.95(0.77-1.13)$ & 48 & $0.93(0.68-1.20)$ \\
\hline 194-195 & Thyroid & 48 & $0.76(0.55-0.98)$ & 35 & $0.62(0.43-0.83)$ \\
\hline 196 & Bone & 7 & $1.09(0.31-2.03)$ & $\leq 3$ & \\
\hline 197 & Connective tissue & 24 & $1.00(0.63-1.42)$ & 4 & $0.52(0.13-1.04)$ \\
\hline 199 & Other & 91 & $1.18(0.95-1.43)$ & 20 & $0.78(0.47-1.13)$ \\
\hline 200,202 & Non-Hodgkin's lymphoma & 108 & $0.93(0.75-1.11)$ & 25 & $0.91(0.58-1.27)$ \\
\hline 201 & Hodgkin's disease & 16 & $0.78(0.44-1.17)$ & 8 & $0.96(0.36-1.68)$ \\
\hline 203 & Multiple myeloma & 32 & $0.82(0.54-1.13)$ & 8 & $0.98(0.37-1.72)$ \\
\hline 204-209 & Leukaemia & 105 & $1.01(0.82-1.22)$ & 18 & $0.65(0.36-0.98)$ \\
\hline \multirow[t]{2}{*}{ 140-209 } & All sites & 3221 & $1.05(1.01-1.09)$ & 938 & $0.83(0.78-0.89)$ \\
\hline & $\geq 5$ years cumulative sea service & 2491 & $1.10(1.06-1.15)$ & 357 & $0.82(0.73-0.90)$ \\
\hline
\end{tabular}

Obs observed cases; $C I$ confidence interval misclassification by not excluding any particular type of sea service.

Lung cancer was the only cancer site where we found an increased risk among women seafarers. We could not corroborate the other findings from the two Nordic studies, which included women seafarers (Pukkala and Saarni 1996; Ugelvig Petersen et al. 2018). Women seafarers in our cohort had worked a substantially less time as seafarers than their male counterparts. However, even when analysing women seafarers with more than 5 years of cumulative sea services, 
Table 4 Standardized Incidence Ratio (SIR) for all and selected cancers among Swedish seafarers, men and women, applying a 10 years' latency from start of exposure (first sea service) ( $n=54926$ ); 1985-2011

\begin{tabular}{|c|c|c|c|c|c|}
\hline \multirow[t]{2}{*}{ ICD-7 } & & \multicolumn{2}{|l|}{ Men } & \multicolumn{2}{|c|}{ Women } \\
\hline & & Obs & $\operatorname{SIR}(95 \% \mathrm{CI})$ & $\overline{\mathrm{Obs}}$ & SIR $(95 \%$ CI $)$ \\
\hline & All & 2912 & $1.06(1.03-1.10)$ & 741 & $0.84(0.78-0.90)$ \\
\hline 140 & Lip & 17 & $1.79(0.95-2.74)$ & $\leq 3$ & \\
\hline $143-148$ & Mouth and pharynx & 72 & $1.76(1.37-2.18)$ & $\leq 3$ & \\
\hline 150 & Oesophagus & 51 & $1.57(1.17-2.00)$ & $\leq 3$ & \\
\hline 161 & Larynx & 42 & $2.08(1.49-2.73)$ & $\leq 3$ & \\
\hline 162.1 & Lung & 327 & $1.57(1.41-1.75)$ & 76 & $1.62(1.26-2.01)$ \\
\hline 181 & Urinary bladder & 203 & $1.19(1.03-1.35)$ & 12 & $0.82(0.41-1.30)$ \\
\hline
\end{tabular}

Obs observed cases; $C I$ confidence interval

Table 5 Standardized Incidence Ratio (SIR) for cancer 1985 to 2011 among all Swedish male merchant seafarers and those ever working on tankers across three calendar periods by first sea service $(<1985,1985-1991,>1992)$

\begin{tabular}{|c|c|c|c|c|c|c|c|}
\hline \multirow[t]{2}{*}{ All male seafarers } & \multicolumn{2}{|c|}{$<1985$} & \multicolumn{2}{|c|}{$1985-1991$} & \multicolumn{2}{|c|}{$>1992$} & \multirow{2}{*}{$\begin{array}{l}\text { Trend } \\
P \text { value }\end{array}$} \\
\hline & Obs & SIR (95\% CI) & Obs & $\operatorname{SIR}(95 \% \mathrm{CI})$ & Obs & $\operatorname{SIR}(95 \% \mathrm{CI})$ & \\
\hline All sites of cancer & 2544 & $1.10(1.06-1.15)$ & 360 & $0.86(0.78-0.96)$ & 317 & $0.93(0.83-1.03)$ & $<0.0001$ \\
\hline Lung cancer & 300 & $1.65(1.47-1.83)$ & 27 & $1.07(0.68-1.51)$ & 14 & $0.76(0.38-1.19)$ & 0.0014 \\
\hline Urinary bladder cancer & 185 & $1.24(1.07-1.43)$ & 18 & $0.84(0.47-1.26)$ & 15 & $0.95(0.51-1.46)$ & 0.1188 \\
\hline \multicolumn{8}{|l|}{ Male tanker seafarers } \\
\hline All sites of cancer & 467 & $1.14(1.04-1.25)$ & 375 & $1.06(0.95-1.17)$ & 99 & $0.93(0.75-1.12)$ & 0.07 \\
\hline Leukaemia $^{\mathrm{a}}$ & 19 & $1.44(0.84-2.13)$ & 18 & $1.52(0.84-2.27)$ & 4 & $0.99(0.25-1.99)$ & $<0.05$ \\
\hline Lymphoma $^{\mathrm{a}}$ & 16 & $1.07(0.60-1.60)$ & 11 & $0.80(0.36-1.31)$ & 4 & $0.94(0.23-1.87)$ & 0.50 \\
\hline
\end{tabular}

Obs observed cases; $C I$ confidence interval

a 1985-2011 Leukaemia SIR 1.41, 95\% CI 1.00-1.86, Lymphoma SIR 0.94, 95\% CI 0.64-1.27

the risk of total cancer was still decreased. The cases were relatively few in number, and we need a longer follow-up for more valid results.

The following argument may indicate an occupational causal factor for cancer in male seafarers: seafarers had more cancer than the general population, the risk increased with a longer cumulated employment ( $>5$ years) and the risk was either unchanged or rather slightly increased when eliminating cancer diagnosis within 10 years after a first sea service. The last part of this argument stems from the fact that the latency of most cancer types can be considered to be $>10-15$ years, leukaemia exempted (Richardson 2008; Manton 2009; Straube et al. 2010; Triebig 2010; CDC 2013; Nadler 2013).

Important confounders when analysing cancer in seafarers may be an elevated use of tobacco and alcohol in seafarers compared to the general population. Although the actual smoking percentage among Swedish seafarers may be as low as $11 \%$ and comparable to the Swedish population, it was around $65-70 \%$ during the 1960 s compared to $50 \%$ in the general population at that time (Nilsson 1998; Forsell et al. 2017). For alcohol consumption, we do not have any reliable data for comparison. However, studies on occupational cancer have shown that there often have to be big differences in smoking or other lifestyle factors should they account for a substantially increased risk (Hadkhale et al. 2019). In a sensitivity analysis on occupational risk of larynx cancer, Kriebel et al. found that large differences in smoking and alcohol consumption could only explain $20 \%$ or less of the associations found (exposure of metalworking fluids) (Kriebel et al. 2004). Rather, co-exposures to smoking and an occupational carcinogen might add up each separate risk ratio even further (thus not confounding but effect interaction), as is the case with lung cancer, asbestos and smoking (Axelson 1989). The same mechanism has been discussed for cancer of the lungs and the urinary bladder and occupational exposures to PAHs and nitroarenes. In our study, the most elevated SIR of lung cancer was noted in engine ratings, where manual work tasks and hence exposure to occupational carcinogens, would be more common. But we have no indication that ratings would smoke more/have more pack-years than officers-who previously themselves often have been ratings, at least in the group of interest here: seafarers with a start at sea before 1985. In summary, it appears possible that carcinogenic occupational factors for lung cancer and cancer of the urinary bladder exist in seafaring, and that they refer to exposures to PAHs present in oils, soot and exhausts (Hadkhale et al. 2019). The effect size of the risk contribution from occupational exposures rest to be assessed. 
Regarding UV radiation, as in other studies, we found an increased risk of lip cancer among male seafarers (Ugelvig Petersen et al. 2018, 2020). But as in the Danish study, we did not find that for malignant melanoma or other skin cancer (Ugelvig Petersen et al. 2018). Asbestos exposure with its long latency time still causes mesothelioma, and as could be expected most of the cases in this study had been working in the engine room. Several other studies have found increased incidence of mesothelioma for male seafarers even if not all of them have been significant (mesothelioma is a rare disease) (Pukkala and Saarni 1996; Ugelvig Petersen et al. 2020).

We found an increased risk of leukaemia for seafaring men that had worked on tankers. Several studies have demonstrated considerate occupational exposures to the leukomogen benzene for the deck crew (Mowe et al. 1977; Moen et al. 1993, 1995; Williams et al. 2005; Kirkeleit et al. 2006; Jacobs et al. 2011). We have shown uptake of benzene and excretion of benzene in alveolar air and urine, together with benzene metabolites, in tanker crewmembers during the mid-1990s (Forsell et al. 2019). Exposure to benzene have probably decreased considerably due to instalment of closed systems for cargo handling and maintenance on board tankers. Decreased occupational exposure appears to have been followed by decreasing incidence of leukaemia, for which we found a significant trend. Smoking is also a risk factor in relation to leukaemia but the seafarers not working on tankers had no increased risk for leukaemia.

The risk of prostate cancer, the most common cancer form in men in the general population, was somewhat decreased in our study. Probably that is a chance finding, since there are conflicting results on the risk of prostate cancer in seafarers (Pukkala and Saarni 1996; Ugelvig Petersen et al. 2020). Regarding thyroid cancer, we have no explanation for the decreased risk in both men and women. One study reported an increased risk of papillary thyroid cancer among male seafarers (Ugelvig Petersen et al. 2020).

\section{Conclusion}

This cohort study of Swedish seafarers active up to 2011 showed an increased risk of cancer in male seafarers with a first sea service before 1985. The risk of total cancer was not increased in women, albeit increased for lung cancer. Several but not all lifestyle-associated cancers were increased in men. The results lend some support to that earlier increased risks of cancer among seafarers are changing to a more normal pattern in modern seafaring.

Acknowledgements We would like to express our sincerest gratitude towards Monica Lundh, Senior Lecturer at Shipping and Marine Technology, Chalmers University of Technology, Senior Officer Johan
Bagge, at the Swedish Maritime Administration and the Swedish Maritime Joint Work Environment Council (SAN) for their professional advice on the trade of seafaring. We are grateful for the statistical assistance offered by Ing-Liss Bryngelsson when analysing the robustness of data and planning the SIR-analyses. The authors declare no conflicts of interest.

Funding Open Access funding provided by University of Gothenburg. The study was funded by AFA Insurance, an organisation owned by Sweden's labour market parties (D-nr 100085), and B-ALF (D-date 20181219). The funders had no role in data management, analysis and interpretation of the results.

Open Access This article is licensed under a Creative Commons Attribution 4.0 International License, which permits use, sharing, adaptation, distribution and reproduction in any medium or format, as long as you give appropriate credit to the original author(s) and the source, provide a link to the Creative Commons licence, and indicate if changes were made. The images or other third party material in this article are included in the article's Creative Commons licence, unless indicated otherwise in a credit line to the material. If material is not included in the article's Creative Commons licence and your intended use is not permitted by statutory regulation or exceeds the permitted use, you will need to obtain permission directly from the copyright holder. To view a copy of this licence, visit http://creativecommons.org/licenses/by/4.0/.

\section{References}

Axelson O (1989) Confounding from smoking in occupational epidemiology. Br J Ind Med 46(8):505-507

Boffetta P, Jourenkova N, Gustavsson P (1997) Cancer risk from occupational and environmental exposure to polycyclic aromatic hydrocarbons. Cancer Causes Control 8(3):444-472

Boffetta P, Dosemeci M, Gridley G, Bath H, Moradi T, Silverman D (2001) Occupational exposure to diesel engine emissions and risk of cancer in Swedish men and women. Cancer Causes Control 12(4):365-374

Breslow NE, Day NE (1987) Statistical methods in cancer research. The design and analysis of cohort studies, vol II. IARC Sci Publ, pp $1-406$

CDC (2013) Minimum Latency \& Types or Categories of Cancer Centers for Disease Control and Prevention (CDC) Monitoring and Treatment 911.

Eriksson HP, Forsell K, Andersson E (2020) Mortality from cardiovascular disease in a cohort of Swedish seafarers. Int Arch Occup Environ Health 93(3):345-353. https://doi.org/10.1007/ s00420-019-01486-5

Forsell K, Hageberg S, Nilsson R (2007) Lung cancer and mesothelioma among engine room crew-case reports with risk assessment of previous and ongoing exposure to carcinogens. Int Marit Health 58(1-4):5-13

Forsell K, Eriksson H, Jarvholm B, Lundh M, Andersson E, Nilsson R (2017) Work environment and safety climate in the Swedish merchant fleet. Int Arch Occup Environ Health 90(2):161-168. https://doi.org/10.1007/s00420-016-1180-0

Forsell K, Liljelind I, Ljungkvist G, Nordlinder R, Andersson E, Nilsson R (2019) Benzene exposure and biomarkers in alveolar air and urine among deck crews on tankers transporting gasoline. Ann Work Expo Health. https://doi.org/10.1093/annweh/wxz055

Forsell K, Bjor O, Jarvholm B, Nilsson R, Andersson E (2020) Hematologic malignancy in tanker crewmembers: a case-referent study among male Swedish seafarers. Am J Ind Med 63(8):685-692. https://doi.org/10.1002/ajim.23122 
Greenberg M (1991) Cancer mortality in merchant seamen. Ann N Y Acad Sci 643:321-332. https://doi.org/10.1111/j.1749-6632. 1991.tb24479.x

Hadkhale K et al (2019) Occupational variation in bladder cancer in Nordic males adjusted with approximated smoking prevalence. Acta Oncol 58(1):29-37. https://doi.org/10.1080/0284186X.2018. 1518591

IARC (1984a) Polynuclear aromatic compounds. Part 1: chemical, environmental and experimental data IARC Monographs on the evaluation of carcinogenic risks to humans Lyon. France 33:95-447

IARC (1984b) Polynuclear aromatic compounds. Part 2: carbon black, mineral oils and some nitroarenes. IARC Working Group on the Evaluation of Carcinogenic Risks to Humans. Lyon, France, pp 93-97

IARC (1987) Asbestos IARC Monographs on the evaluation of carcinogenic risks to humans. France, Lyon, p 106

IARC (2006) Polycyclic aromatic hydrocarbons IARC Working Group on the Evaluation of Carcinogenic Risks to Humans. Lyon, France

IARC (2012) Arsenic, metals, fibres, and dusts. Volume $100 \mathrm{C} \mathrm{A}$ review of human carcinogens IARC Monographs on the Evaluation of Carcinogenic Risks to Humans. IARC, pp 219-294

IARC (2013) Diesel and Gasoline Engine Exhausts and Some Nitroarenes IARC Monographs on the Evaluation of Carcinogenic Risks to Humans. vol 105

IARC (2018) Solar and ultraviolet radiation. Radiation IARC Monographs on the Evaluation of Carcinogenic Risks to Humans volume 100c. IARC, pp 35-101

IMO (1974) International Convention for the Safety of Life at Sea (SOLAS).

IMO (2000) International Convention for the Safety of Life at Sea (SOLAS) - amendment in 2000.

IMO (2003) Revised minimum safety standards for ships carrying liquids in bulk containing benzene In: IMO (ed). vol MSC/ Circ.1095. IMO

IMO (2011) International Convention for the Safety of Life at Sea (SOLAS) —amendment in 2011.

Jacobs W et al (2011) Benzene concentrations on board chemical tankers. WMU J Marit Affairs 10:117-126. https://doi.org/10.1007/ s13437-010-0002-6

Kaerlev L, Hansen J, Hansen HL, Nielsen PS (2005) Cancer incidence among Danish seafarers: a population based cohort study. Occup Environ Med 62(11):761-765

Kirkeleit J, Riise T, Bratveit M, Moen BE (2006) Benzene exposure on a crude oil production vessel. Ann Occup Hyg 50(2):123-129. https://doi.org/10.1093/annhyg/mei065

Kriebel D, Zeka A, Eisen EA, Wegman DH (2004) Quantitative evaluation of the effects of uncontrolled confounding by alcohol and tobacco in occupational cancer studies. Int J Epidemiol 33(5):1040-1045. https://doi.org/10.1093/ije/dyh151

Manton KGA, Kravchenko J (2009) Cancer mortality and morbidity patterns in the US population. Springer Science+Business Media, New York

Moen BE, Riise T, Todnem K, Fossan GO (1988) Seamen exposed to organic solvents. A cross-sectional study with special reference to the nervous system. Acta Neurol Scand 78(2):123-135

Moen BE, Hollund BE, Berntsen M, Flo R, Kyvik KR, Riise T (1993) Chemical exposure of deck crew on product tankers loading the cargo with the hatches open. Bull Inst Marit Trop Med Gdyn 44-45(1-4):65-73

Moen BE, Hollund BE, Berntsen M, Flo R, Kyvik KR, Riise T (1995) Exposure of the deck crew to carcinogenic agents on oil product tankers. Ann Occup Hyg 39(3):347-361. https://doi.org/10.1016/ 0003-4878(95)00005-y

Moen BE et al (1996) Assessment of exposure to polycyclic aromatic hydrocarbons in engine rooms by measurement of urinary 1-hydroxypyrene. Occup Environ Med 53(10):692-696
Mowe G, Simonsen O, Weimundsen B (1977) Sjøfolk i kjemikaliefart : kjemiske, miljø- og helseproblemer blant mannskap på skip som frakter flytende kjemikalier i bulk. Yrkeshygienisk Institutt Oslo

Nadler DLZIG (2013) Developing a Weibull model extension to estimate cancer latency. ISRN Epidemiol. https://doi.org/10.5402/ 2013/750857

Nilsson R (1998) Cancer in seamen with special reference to chemical health hazards. Thesis. Göteborg University, Sweden

Nilsson RI, Nordlinder RG, Tagesson C, Walles S, Jarvholm BG (1996) Genotoxic effects in workers exposed to low levels of benzene from gasoline. Am J Ind Med 30(3):317-324. https://doi.org/10. 1002/(SICI)1097-0274(199609)30:3\%3c317::AID-AJIM10\% 3e3.0.CO;2-Z[pii]

Nilsson R, Nordlinder R, Hörte L, Järvholm B (1998) Leukemia, lymphoma, and multiple myeloma in seamen on tankers. Occup Environ Med 55(8):517-521

Nilsson R et al (2004) Increased urinary excretion of 8-hydroxydeoxyguanosine in engine room personnel exposed to polycyclic aromatic hydrocarbons. Occup Environ Med 61(8):692-696. https:// doi.org/10.1136/oem.2003.00743561/8/692[pii]

Oldenburg M, Harth V, Manuwald U (2015) Hospitalization due to cancer among German seafarers. Am J Ind Med 58(4):456-463. https://doi.org/10.1002/ajim.22423

Olsson AC et al (2010) Occupational exposure to polycyclic aromatic hydrocarbons and lung cancer risk: a multicenter study in Europe. Occup Environ Med 67(2):98-103. https://doi.org/10.1136/oem. 2009.046680

Pukkala E, Saarni H (1996) Cancer incidence among Finnish seafarers, 1967-92. Cancer Causes Control 7(2):231-239

Pukkala E et al (2009) Occupation and cancer - follow-up of 15 million people in five Nordic countries. Acta Oncol 48(5):646-790. https://doi.org/10.1080/02841860902913546

Rafnsson V, Sulem P (2003) Cancer incidence among marine engineers, a population-based study (Iceland). Cancer Causes Control 14(1):29-35

Richardson DB (2008) Temporal variation in the association between benzene and leukemia mortality. Environ Health Perspect 116(3):370-374. https://doi.org/10.1289/ehp.10841

Saarni H, Pentti J, Pukkala E (2002) Cancer at sea: a case-control study among male Finnish seafarers. Occup Environ Med 59(9):613-619

Straube S, Westphal GA, Hallier E (2010) Comment on: Implications of latency period between benzene exposure and development of leukemia-a synopsis of literature. Chem Biol Interact 186(2):248-249

Triebig G (2010) Implications of latency period between benzene exposure and development of leukemia-a synopsis of literature. Chem Biol Interact 184(1-2):26-29. https://doi.org/10.1016/j.cbi. 2009.12.014

Ugelvig Petersen K, Volk J, Kaerlev L, Lyngbeck Hansen H, Hansen J (2018) Cancer incidence among merchant seafarers: an extended follow-up of a Danish cohort. Occup Environ Med 75(8):582-585. https://doi.org/10.1136/oemed-2018-105037

Ugelvig Petersen K et al (2020) Cancer incidence among seafarers and fishermen in the Nordic countries. Scand J Work Environ Health 46(5):461-468. https://doi.org/10.5271/sjweh.3879

Williams PR, Robinson K, Paustenbach DJ (2005) Benzene exposures associated with tasks performed on marine vessels (circa 1975 to 2000). J Occup Environ Hyg 2(11):586-599. https://doi.org/10. 1080/15459620500339147

Publisher's Note Springer Nature remains neutral with regard to jurisdictional claims in published maps and institutional affiliations. 